\title{
Evolutionary Genetics of Invasive Mammal Species Introduced in Argentina
}

\author{
Marta S. Lizarralde ${ }^{1,2}$, Mariana Fasanella ${ }^{3}$, Sebastián Poljak ${ }^{1,2,4}$, \\ Magali Gabrielli2 ${ }^{2}$ Julieta Sanchez ${ }^{1,2,4}$
}

\begin{abstract}
${ }^{1}$ Lab de Ecologia Molecular, Centro Austral de Investigaciones Científicas, CADIC-CONICET. Av. Houssay, Ushuaia, Argentina; ${ }^{2}$ Lab. Ecologia Molecular, Centro Regional de Estudios Genómicos-FCE-UNLP. La Plata, Argentina; ${ }^{3}$ Lab. Ecotono, Instituto de Investigaciones en Biodiversidad y Medio Ambiente, INIBIOMA-CONICET. Bariloche, Argentina; ${ }^{4} \mathrm{ICPA}$, Universidad Nacional de Tierra del Fuego, Ushuaia. Tierra del Fuego, Argentina
\end{abstract}

Correspondence to: Marta S. Lizarralde, mlizarralde@cadic-conicet.gob.ar

Keywords: Evolutionary, Genetics, Invasive, Mammals, Argentina

Received: March 21, $2018 \quad$ Accepted: July 3, $2018 \quad$ Published: July 6, 2018

Copyright $\odot 2018$ by authors and Scientific Research Publishing Inc.

This work is licensed under the Creative Commons Attribution International License (CC BY 4.0).

http://creativecommons.org/licenses/by/4.0/

\section{(c) (1) Open Access}

\section{ABSTRACT}

Evolutionary genetics of invasive species has been unexplored in Argentina. Invasive alien species (IAS) have a wide geographical distribution, characteristic life cycles and great ability to adapt, establish and spread in a new environment. Recent advances in novel molecular technologies, the use of higher resolution genetic markers, and the research development on genetic variation of invasive species consolidated the importance of genetic aspects in the invasion process. Undoubtedly, the growing concern for the disturbances generated by invasive species on biodiversity and functioning of ecosystems was also determinant for the inclusion of the Invasion Biology within the broad field of Evolutionary Biology including relevant examples that address the evolutionary genetic aspects of biological invasions. Recent studies suggest that the invasion success of many species depends on their ability to respond to natural selection. Although the number of invasive species registered in Argentina far exceeds 600 , little research has been done on invasive mammal species and only five of them were hitherto genetically analyzed. Presuming that invasion genetics is incorporated into the agenda of control and management organizations, it would allow integrating the ecological, genetic, and evolutionary biology aspects for knowledge of invasive species widely distributed in Argentina. The objective of this article is to highlight the importance of evaluating the genetic structure of invasive species for their management and to inform about the invasive species of mammals that were introduced in Argentina and have been or are being analyzed genetically. 


\section{INTRODUCTION}

Invasive alien species (IAS) have always raised interest, not only because of their distinctive characteristics of wide distribution and life cycles, but also because of their ability for adaptation, establishment and expansion in a new environment, which allow them to become successful invaders. Invasive species and populations pose major threats to biodiversity, ecosystem integrity, agriculture, fisheries, and public health. One of the characteristics of IAS is that they are easily adaptable to new habitats, thus allowing them to increase their population size and geographic distribution rapidly. Environmental damage and disturbances caused by invasive species represent significant economic costs for various activities, also involving health risk situations [1]. Certainly, they are the main cause of extinction, retraction and restructuration of biological populations [2-4].

After an introduction, different events of the colonization process will determine that only a limited number of species will be established as successful colonizers [5, 6]. Although most introductions fail at this stage, species that successfully adapt to the new environment may become highly invasive, achieving a rapid expansion. Usually, the expansion of the invasion has important evolutionary biology and genetic consequences that are transferred from one place to another, and that could influence the probability of establishment, the future distribution and the adaptability of the invasive species. If the adaptive response occurs in the short-term, these cases become true natural experiments, which are very useful for the study of ecological and evolutionary biology responses. By contrast, genetic evolutionary invasions have remained relatively unexplored probably by the early dissociation between studies on the ecology of invasions and studies related to genetics and evolution of introduced non-native species. In the last few years, DNA-based methods were developed for the detection, identification and monitoring of invasive species [7] and for the analysis of the variability and genetic structure of populations (e.g. [8-11]), to apply these results to the knowledge to management, control and/or eradication of invasive species. These advances led to the increased use of genetic markers in the development of evolutionary and molecular ecology and concentrated large investigations on genetic variability of invasive species, consolidated the importance of evolutionary genetic aspects in invasive processes.

Studies on invasive genetics have increased gradually, with the aim of identifying the determinants of invasiveness and the traits that characterize IAS using genetic markers to phylogenetic and phylogeographic analyses, and other experimental approaches, which include historical, biogeographical, and ecosystem factors. Certainly, invasion genetics is a tool for reconstructing the biogeographic and evolutionary history of invasions, evaluating among other things, the magnitude of genetic bottlenecks and founding events. Both evolutionary processes can drastically reduce genetic variability (gene drift), and consequently it is expected that introduced species might have limited potential to adapt to new environments.

The genetic approach provides a way to solve the genetic paradox of biological invasion, i.e. "how introduced populations, whose genetic variation has been depressed by a genetic bottleneck or founding effect, persist and adapt to new conditions" [12]. Despite this, the adaptive potential of some invasive species might be significant.

Although both phenotypic plasticity and epigenetic variation have also been proposed as compensatory for this lack of genetic variation [13], many invasive species may have being benefited from repeated introductions, increasing genetic variation into the new habitat. For example, one factor that contributes to the adaptive potential of introduced species and that could contribute to the invasion success is the intraspecific hybridization (admixture) produced by multiple introductions from different native populations into one area $[12,14-16]$. In addition, some invasive populations showed greater genetic diversity when compared to native populations $[17,18]$.

It is important to note that there are increasingly more studies reporting evolutionary changes in invasive populations at ecological times, such as the case of copepods adapted to different salinities [13, 19], Drosophila [20], rabbits [21] and Solidago [22].

One of the key factors in the invasion genetics is that if we want to study adaptation of introduced species to new environments, we have to stop using neutral markers and begin determining how particular 
gene variation influences the introduction and successful expansion of species.

Recent advances in molecular tools will undoubtedly provide great contributions to genetic studies. Particularly, there are several new technologies for the analysis of genetic variability in invasive species that use a variety of molecular markers. For example, DNA barcoding [23] will enable rapid identification of invasive species, allowing quarantine and eradication efforts to begin far earlier, with significant reductions in costs and increased chances of success.

Also, the Metabarcoding or Environmental DNA (eDNA) are surveillance tools used to monitor for the genetic presence of a species in a variety of environmental samples that have many potentially invasive species, the presence of the targeted invasive species can be confirmed through the direct detection of its DNA. The increased sensitivity of this technique could be a valuable tool not only for invasive species but also for threatened and endangered species as well. Furthermore, early detection by Metabarcoding can significantly reduce costs in managing the invasive species.

Genomics is an extremely powerful tool for reconstructing the evolutionary history of invasive species [24] and enables scientists to differentiate between neutral (i.e. those changes in which natural selection does not affect their spread in a species) and positive DNA changes (i.e. those that improve chances of survival and reproduction of an organism and thus spread through a population). This positively selected evolution drives the fast adaptation of invasive species. Consequently, by understanding the effects of positive evolution we can predict how species could be able to adapt in the future.

Invasion genetics is slowly proceeding to invasion genomics. Both disciplines provide a cost-effective solution to the monitoring and management of invasive species. Therefore, studies using these new technologies will be key for analyzing the functional role of candidate loci and will represent a step forward for invasion genetics.

The remarkable increase in research on biological invasions in Latin America in the last decades is to integrate invasive genetics with other approaches, such as demographic and ecological [25]. Although there are very few studies in Argentina that integrate genetic and ecological data of invasive alien species, which therefore represent a new field to explore. It should be noted that so far in our country, no management or eradication plans have employed eDNA or genetic/genomic information.

\section{GENETIC STUDIES OF INVASIVE MAMMALS INTRODUCED IN ARGENTINA}

In Argentina there are more than 600 alien or non-native species

(http://www.institutohorus.org.br/iabin/i3n/), of which approximately 149 are wildlife (animal) species. In particular, during the last decades, the introduction and effects of several species of non-native wild mammals have been documented. However, the existing information on these species is limited, even of those invasive mammal species that cause innumerable inconveniences and disturbances in diverse ecosystems of our country [26].

According to different references, we consider there are 23 [27] or 27 [26] invasive alien mammal species, without considering those of continental presence that were introduced into islands, such as the grey fox (Dusicyon griseus) and the big hairy armadillo (Chaetophractus villosus) introduced into Isla Grande de Tierra del Fuego. Five of the existing invasive species have either a molecular genetic approach analyzing the population genetic structure and variability, or some preliminary data that requires further research. These invasive species are: 1) the beaver, Castor canadensis [28-31], 2) the red bellied squirrel [32], 3) the rabbit [33], 4) the wild boar, Sus scrofa [34-36], and 5) the big hairy armadillo [37] (Table 1).

Beaver invasion is certainly one of the most complex topics regarding invasive mammals in Argentina, and a molecular biology approach would allow integrating different strategies to ensure a successful management program of this invasive mammal. Beavers were introduced on the Isla Grande de Tierra del Fuego and are responsible for the most drastic landscape alteration since the last glacial age, affecting not only the hydrology and composition of the southern beech forest but also and more importantly, allowing other exotic species to invade the ecosystem. From 20 individuals intentionally released in 1946 [38], 
Table 1. Molecular technology applied to genetic studies of invasive mammalian species introduced in Argentina.

\begin{tabular}{|c|c|c|c|}
\hline Species Name & Molecular Markers ${ }^{\mathrm{a}}$ & Accession Number & References \\
\hline Castor canadensis & $\begin{array}{c}\text { D-loop, COI } \\
\text { Microsatellites }\end{array}$ & $\begin{array}{l}\text { AY787822-27 } \\
\text { EU } 476079^{\mathrm{b}}\end{array}$ & {$[29-31]$} \\
\hline $\begin{array}{c}\text { Callosciurus } \\
\text { finlaysonii/erythraeus }\end{array}$ & $\begin{array}{c}\text { COI, Cyt b, D-loop } \\
\text { RAG1 }\end{array}$ & $\begin{array}{l}\text { KF786004-26 } \\
\text { KF786037-40 } \\
\text { KF856211-30 }\end{array}$ & {$[32]$} \\
\hline Oryctolagus cuniculus & Cyt b, D-loop & $\mathrm{ND}^{\mathrm{e}}$ & [33] \\
\hline Sus scrofa & D-loop, COI, Cyt b & $\begin{array}{c}\text { AAA3445 } 5^{\mathrm{cd}} \\
\end{array}$ & [34-36] \\
\hline Chaetophractus villosus. & D-loop, COI & $\begin{array}{l}\text { EU019190-94 } \\
\text { EU100942-44 } \\
\text { FJ544909-13 }\end{array}$ & {$[37]$} \\
\hline
\end{tabular}

a'Locus: RAG1, recombination activating gene 1; D-loop, the control region of mitochondrial DNA; COI, mitochondrial cytochrome oxidase $\mathrm{c}$ subunit I gene; Cyt b, mitochondrial cytochrome b gene. ${ }^{\mathrm{b}} \mathrm{GenBank}$ accession numbers. ${ }^{\mathrm{c} A c c e s s i o n}$ numbers in Barcode Index (BOLD). ${ }^{\mathrm{d}}$ GenBank accession number in progress. ${ }^{\mathrm{e}}$ No data available.

beavers have increased their numbers to a current population size of approximately 100,000 or more individuals. Our studies analyzing the genetic variability and population structure of mitochondrial DNA of this species in the archipelago of Tierra del Fuego showed the presence of seven linages, three of them that proved to be the most abundant and distributed throughout the archipelago [29-31] (Figure 1). We concluded that the main island (Isla Grande) should be considered a single management unit (MU) and every small island in the archipelago a separate MU. We also proposed control and management measures considering that it was not possible to identify eradication units (EU) clearly in Isla Grande, given that the Strait of Magellan is the only geographic barrier that would prevent gene flow in the population. This scenario makes difficult to decide whether eradicating, controlling or even tolerating the species is the most convenient strategy.

The genetic characterization of asiatic species of Callosciurus squirrels ( $C$. finlaysonii and $C$. erythraeus) introduced into Argentina was also studied by [32] to compare them with native and introduced populations into Asia. The genetic variation in mitochondrial and nuclear DNA markers between the four invasion foci in Argentina was analyzed to corroborate the pathway of invasion. Sequences from Asiatic squirrels introduced into Argentina were related to Callosciurus finlaysonii according to D-loop and Cytochrome b mitochondrial markers (Figure 1). Additionally, introduced squirrels from the different invasion foci formed a monophyletic group that, together with one haplotype for the D-loop and COI (Cytochrome c oxidase subunit I) markers supported the hypothesis of one single introduction event into Argentina followed by subsequent translocations. The phylogeny of $C$. erythraeus and $C$. finlaysonii and their different subspecies is not yet resolved, since intraspecific variation among sequences of Callosciurus belonging to different subspecies or collected from different regions is large and comparable with the distance to the sequences from Argentina. Reference [32] finally concluded that the genetic and intraspecific variations between Callosciurus species require further research, in order to obtain a more comprehensive phylogeny. This demonstrates the need for applying genetic studies to get a clear understanding of the parental origin of introduced populations and an updated review of their phylogenies. 


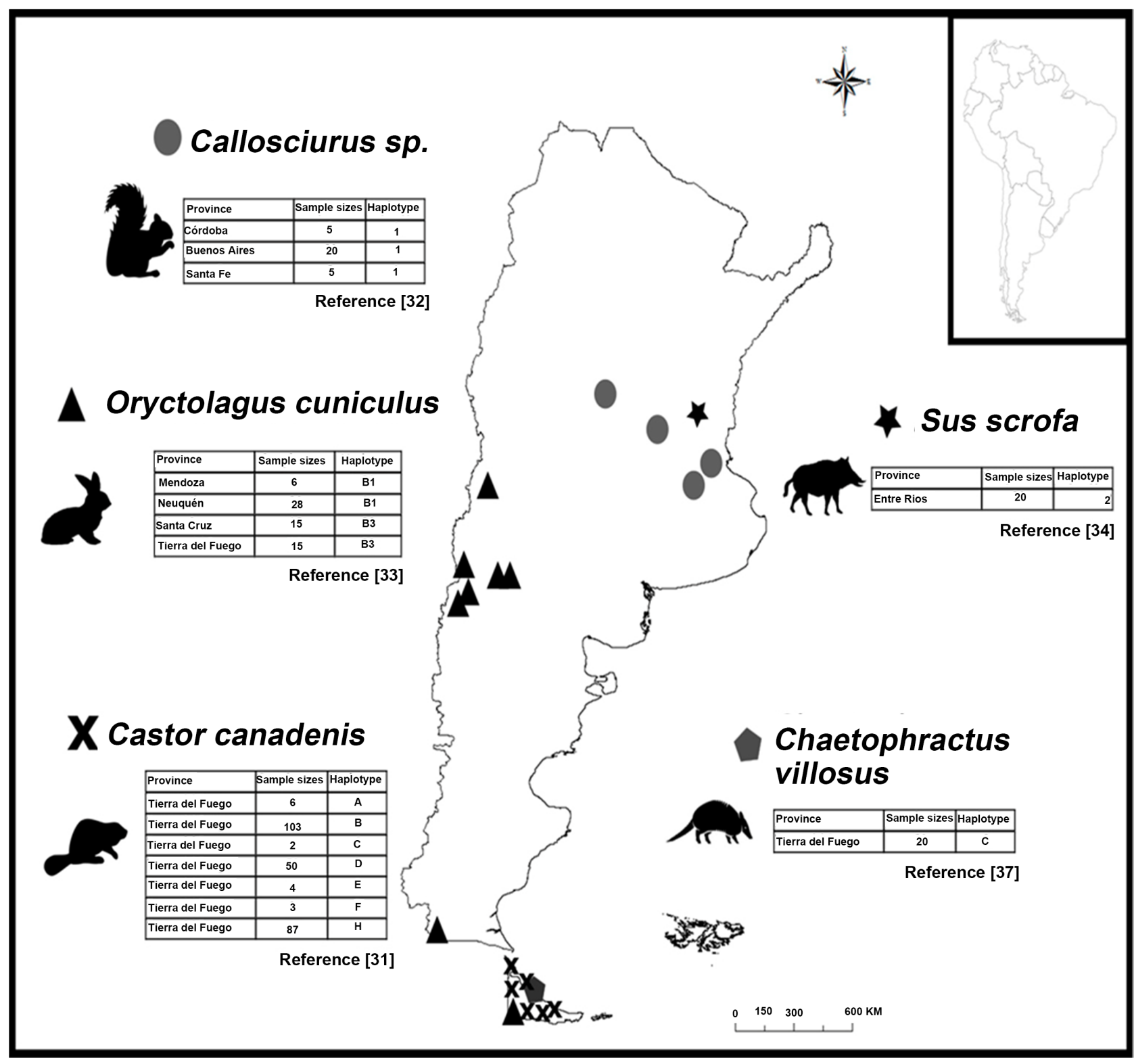

Figure 1. Geographical distribution and main results about studies carried on mammal invasive species introduced in Argentina. Symbols indicate the invasive species and geographical location of the samples analyzed. Table references of each invasive species are as follow: Province = geographical location; Sample sizes $=$ number of individual analyzed and Haplotype (i.e. B1, B3, 1, A, B, C, etc.) $=$ name of haplotype identified by the authors.

Rabbits (Oryctolagus cuniculus) is another mammal species that invaded Argentina throughout the continental and insular Patagonia (Tierra del Fuego). A genetic study of Patagonian populations [33] determined the main existing lineages and the genealogical relationship between rabbit populations introduced in Argentina and their original distributions (Figure 1). It is undoubtedly that there is still much to investigate in relation to intra and inter-population genetic variability of this species and its implication in the identification of management units and implementation of control actions.

A similar situation arises from studies on the genetic structure of wild boar ( $S$. scrofa). References [34, 35] analyzed a fragment of control region (mitochondrial DNA) in the introduced population from El 
Palmar National Park (Entre Ríos) and identified new haplotypes of great homology with reference haplotypes of pig breed populations autochthonous from Asia (Figure 1). Also [36] by analyzing another mitochondrial marker confirmed what was preliminarily observed by $[34,35]$ but also proposed that the origin of the remaining wild boars from Central and South Argentina is also related to European populations suggesting the existence of multiple wild boar introductions in Argentina. Nevertheless, it is still necessary to unravel the complex genetic structure in the original populations which is marked by domestication events in Asia and Europe, large numbers of breeds, introgression of Asian genome into the breeds and the interbreeding of domesticated and wild boars $[39,40]$. The characteristics of an expanding invasive species are combined with the decrease in populations of pure specimens by hunting pressure and reduction of habitats. The spread of the wild boar to the north of Argentina, and the contact with phylogenetically close species ( Tayassuidae), also suggests the possibility of genetic introgression between them.

Large hairy armadillo Chaetophractus villosus is a particular case of invasive species because it is native to continental region of Argentina however it was introduced by humans in the Isla Grande de Tierra del Fuego in 1982 [37, 41]. All armadillos from Patagonia and Tierra del Fuego belong to the same mitochondrial linage (Figure 1). Recent monitoring of populations of this species in Isla Grande shows that their distribution range has increased since its introduction (Poljak et al., unpublished).

\section{MANAGEMENT AND GENETIC CONTROL OF INVASIVE SPECIES}

Certainly, it is important to discuss the implications on the incorporation of evolutionary genetics to determine the success of the invasion and consequently, its usefulness for the management and genetic control of IAS. In particular, knowledge about genetic structure of invasive species is extremely informative to generate mitigation and management strategies. Moreover, comparing genetic variation within and between invasive populations enables biologists to understand how invading species spread, intermingle and compete with native species. Basically, elucidate the genetic consequences of introductions is essential aspect for the effective management of invasive species and for sustainable policy decisions.

At present, molecular techniques enhance management of invasive species, they are faster, more specific and have greater standardization than surveillance programs based on morphological identification [42]. Biologists use molecular techniques to catch invasions earlier by detecting animals' DNA in the environment (eDNA) from skin, urine, faeces, air, sediment, soil or water samples and is an indirect genetic method for detection of rare and cryptic species [43]. In addition, markers such as microsatellites, nuclear and mitochondrial DNA have been widely used to understand population dynamics of different pests and disease vectors, helping control programs to limit their impact, as in the case of some mammal species [9, 29, 30, 32, 44-47].

Also genetic control strategies, which involve genetic engineering, are area-wide and species-specific methods. This species-specific aspect is very attractive from an environmental perspective, as it targets the species of interest [48]. The most common management genetic-based strategy for population suppression that uses classical genetics for biological insect control is the Sterile Insect Technique (SIT) [49]. This technique has been used successfully for more than 50 years against several major agricultural pests, using radiation-sterilized insects. In Argentina, this technique has been employed mainly in agricultural regions where insects cause large losses in fruit and vegetable production.

More recently, Clustered Regularly Interspaced Short Palindromic Repeats (CRISPR)-Cas9 is a novel technology of great potential for controlling invasive species and its development has resumed discussions on the use of gene drive for invasive species control [50]. Once transgenic organisms bearing the gene drive are constructed in the laboratory, they must be released into the wild to mate with wild-type individuals, in order to begin the process of spreading the drive to wild populations. This technology can be applied for controlling or even eradicating invasive species from islands or even possibly from entire continents, but this can also have risks related to undesired spread. Firstly, rare mating events may allow the drive to affect closely related species and secondly, this could spread from the invasive population back into the native habitat. Because this technology involves transgenic organisms, experiments are not com- 
pletely without risk.

Much remains to be done in terms of genetic control using modified organisms, so we believe that making a consultative and regulated risk-cost-benefit analysis in a biosecurity context might be a careful step forward before the use of gene drive technologies in invasive species populations.

Therefore, researchers, policymakers, and resource managers must carefully evaluate implementation risks of molecular genetic technologies that could threaten rather than assist a given ecosystem [51]. Definitely, understanding these interactions has broad practical application for the control and management of invasive species.

According to the current situation, we consider it would be useful to detect the population structure of invasive species introduced in Argentina through analysis of mitochondrial and nuclear DNA, as well as environmental DNA. In this way, genetic information can be applied in conjunction with traditional eradication and control measures in order to management invasive species. It is also extremely important to inform and encourage education of researchers, policymakers, resource managers and people in general, in order to avoid new introductions of exotic species.

In other words, genomic tools are extremely useful for the management and control of IAS. Although they may be considered too expensive for the resources allocated to natural resource offices or government administrations, several studies (see above) have shown that they are actually much more effective than traditional monitoring tools.

\section{CONCLUSIONS}

Despite the considerable number of mammal species introduced in Argentina [26, 27, 52], no genetic studies have been carried out for almost any of these species, not even descriptive studies suggesting the need to relate ecological aspects and population genetics. There is still much to be known about the adaptations of invasive species to the new environments in which they inhabit and about the potential of many other species that are not yet invasive. Without doubt, the early detection of potentially invasive species, after their introduction, when populations are still limited to a small area and a low density, maximizes the probability of effective management [53].

Actually, the knowledge about molecular data to understand invasive species dispersal and adaptation has valuable applications mainly when these aspects are urgently required. We believe that the extensive experience of regulatory successes and failures in the context of classical biological control offers a framework to provide meaningful guidance for assessing risks and benefits for applications related to invasive species control within this emerging field.

Basically, new genomic tools provide an unprecedented view of past and present population processes and add much more than simply improving the detection and understanding of the expansion. High-density markers are used to detect changes in different parts of the genome, processes of hybridization and introgression, and adaptation to the climate change. An increase in the rate of biological invasions directly related to the increase in climate change effects is expected on biological communities, particularly when events of habitat disturbances that facilitate the establishment of IAS occur [54].

Invasion biology has recognized that the direction of research is clearly changing [55]. Although most studies hitherto are purely ecological (at the level of organisms, species, populations, or ecosystems), we need to recognize the usefulness and increasing growth of genetic studies and the significance of evolutionary processes in invasive species for generating management actions and controlling the impact of biological invasions. More recently, there has been a resurgence of interest in this subject. Indeed, the significance of the genetic approach and the evolutionary perspective is now globally recognized as important not only for understanding the species' ability to move forward through different stages of the invasion but also for improving management interventions that could reduce rates and impacts of invasions.

Countless genomic tools can be used to allow society to reduce the economic cost of biological invasions by optimizing their management and control. To mitigate these costs, it is necessary to better understand the causes, consequences and progression of the invasion. Consequently, the genetic information 
will serve to identify and predict the risk of the source populations and address the problem when possible invasions are detected.

\section{REFERENCES}

1. Mack, R.N., Simberloff, D., Lonsdale, M.W., Evans, H., Clout, M., et al. (2000) Biotic Invasions: Causes, Epidemiology, Global Consequences and Control. Ecological Applications, 10, 689-710. https://doi.org/10.1890/1051-0761(2000)010[0689:BICEGC]2.0.CO;2

2. Williamson, M. (1996) Biological Invasions. Chapman \& Hall, London, 244 p.

3. Cox, G.W. (2004) Alien Species and Evolution: The Evolutionary Ecology of Exotic Plants, Animals, Microbes, and Interacting Native Species.

4. Sax, D.F., Stachowicz, J.J. and Gaines, S.D. (2005) Species Invasions: Insights into Ecology, Evolution and Biogeography.

5. Lee, C.E. (2002) Evolutionary Genetics of Invasive Species. Trends in Ecology \& Evolution, 17, 386-391. https://doi.org/10.1016/S0169-5347(02)02554-5

6. Gilchrist, G.W. and Lee, C.E. (2007) All Stressed out and Nowhere to Go: Does Evolvability Limit Adaptation in Invasive Species? Genetica, 129, 127-132. https://doi.org/10.1007/s10709-006-9009-5

7. Darling, J.A. and Blum, M.J. (2007) DNA-Based Methods for Monitoring Invasive Species: A Review and Prospectus. Biological Invasions, 9, 751-765. https://doi.org/10.1007/s10530-006-9079-4

8. Tsutsui, N.D., Suarez, A.V., Holway, D.A. and Case, T.J. (2000) Reduced Genetic Variation and the Success of an Invasive Species. Proceedings of the National Academy of Sciences, 97, 5948-5953. https://doi.org/10.1073/pnas.100110397

9. Abdelkrim, J., Pascal, M., Calmet, C. and Samadi, S. (2005) Importance of Assessing Population Genetic Structure before Eradication of Invasive Species: Examples from Insular Norway Rat Populations. Conservation Biology, 19, 1509-1518. https://doi.org/10.1111/j.1523-1739.2005.00206.x

10. Zhan, A., Darling, J.A., Bock, D.G., Lacoursière-Roussel, A., MacIsaac, H.J., et al. (2012) Complex Genetic Patterns in Closely Related Colonizing Invasive Species. Ecology and Evolution, 2, 1331-1346. https://doi.org/10.1002/ece3.258

11. Chau, L.M., Hanna, C., Jenkins, L.T., Kutner, R.E., Burns, E.A., et al. (2015) Population Genetic Structure of the Predatory, Social Wasp Vespula pensylvanica in Its Native and Invasive Range. Ecology and Evolution, 5, 5573-5587. https://doi.org/10.1002/ece3.1757

12. Sakai, A.K., Allendorf, F.W., Holt, J.S., Lodge, D.M., Molofsky, J., et al. (2001) The Population Biology of Invasive Species. Annual Review of Ecology and Systematics, 32, 305-332.

https://doi.org/10.1146/annurev.ecolsys.32.081501.114037

13. Liebl, A.L., Schrey, A.W., Andrew, S.C., Sheldon, E.L. and Griffith, S.C. (2015) Invasion Genetics: Lessons from a Ubiquitous Bird, the House Sparrow Passer Domestics. Current Zoology, 61, 465-476.

https://doi.org/10.1093/czoolo/61.3.465

14. Keller, S. and Taylor, D. (2010) Genomic Admixture Increases Fitness during a Biological Invasion. Journal of Evolutionary Biology, 23, 1720-1731. https://doi.org/10.1111/j.1420-9101.2010.02037.x

15. Verhoeven, K.J., Macel, M., Wolfe, L.M. and Biere, A. (2011) Population Admixture, Biological Invasions and the Balance between Local Adaptation and Inbreeding Depression. Proceedings of the Royal Society of London B: Biological Sciences, 278, 2-8. https://doi.org/10.1098/rspb.2010.1272

16. Estoup, A., Ravigné, V., Hufbauer, R., Vitalis, R., Gautier, M., et al. (2016) Is There a Genetic Paradox of Biological Invasion? Annual Review of Ecology, Evolution, and Systematics, 47, 51-72. 
https://doi.org/10.1146/annurev-ecolsys-121415-032116

17. Kolbe, J.J., Glor, R.E., Schettino, L.R., Lara, A.C., Larson, A., et al. (2004) Genetic Variation Increases during Biological Invasion by a Cuban Lizard. Nature, 431, 177. https://doi.org/10.1038/nature02807

18. Lavergne, S. and Molofsky, J. (2007) Increased Genetic Variation and Evolutionary Potential Drive the Success of an Invasive Grass. Proceedings of the National Academy of Sciences, 104, 3883-3888. https://doi.org/10.1073/pnas.0607324104

19. Lee, C.E. and Petersen, C.H. (2002) Genotype-by-Environment Interaction for Salinity Tolerance in the Freshwater-Invading Copepod Eurytemora affinis. Physiological and Biochemical Zoology, 75, 335-344. https://doi.org/10.1086/343138

20. Huey, R.B., Gilchrist, G.W., Carlson, M.L., Berrigan, D. and Serra, L.S. (2000) Rapid Evolution of a Geographic Cline in Size in an Introduced Fly. Science, 287, 308-309. https://doi.org/10.1126/science.287.5451.308

21. Williams, C.K. and Moore, R. (1989) Phenotypic Adaptation and Natural Selection in the Wild Rabbit, Oryctolagus cuniculus, in Australia. The Journal of Animal Ecology, 495-507. https://doi.org/10.2307/4844

22. Weber, E. and Schmid, B. (1998) Latitudinal Population Differentiation in Two Species of Solidago (Asteraceae) Introduced into Europe. American Journal of Botany, 85, 1110-1121. https://doi.org/10.2307/2446344

23. Hebert, P.D., Cywinska, A. and Ball, S.L. (2003) Biological Identifications through DNA Barcodes. Proceedings of the Royal Society of London B: Biological Sciences, 270, 313-321. https://doi.org/10.1098/rspb.2002.2218

24. Luikart, G., England, P.R., Tallmon, D., Jordan, S. and Taberlet, P. (2003) The Power and Promise of Population Genomics: From Genotyping to Genome Typing. Nature Reviews Genetics, 4, 981-994.

https://doi.org/10.1038/nrg1226

25. Quiroz, C.L., Pauchard, A., Cavieres, L.A. and Anderson, C.B. (2009) Análisis Cuantitativo de la investigación en invasiones biológicas en Chile: Tendencias y desafíos. Revista Chilena de Historia Natural, 82, 497-505. https://doi.org/10.4067/S0716-078X2009000400005

26. Lizarralde, M. (2016) Especies exóticas invasoras (EEI) en Argentina: Categorización de mamíferos invasores y alternativas de manejo. Mastozoología Neotropical, 23, 267-277.

27. Ballari, S.A., Anderson, C.B. and Valenzuela, A.E. (2016) Understanding Trends in Biological Invasions by Introduced Mammals in Southern South America: A Review of Research and Management. Mammal Review, 46, 229-240. https://doi.org/10.1111/mam.12065

28. Lizarralde, M., Escobar, J. and Deferrari, G. (2004) Invader Species in Argentina: A Review about the Beaver (Castor canadensis) Population Situation on Tierra del Fuego Ecosystem. Interciencia, 29, 352-356.

29. Lizarralde, M., Escobar, J., Deferrari, G. and Fasanella, M. (2008) El castor austral. Investigación y ciencia, 379, 58-64.

30. Fasanella, M., Poljak, S. and Lizarralde, M.S. (2010) Invasive North American Beaver (Castor canadensis): The Distribution of Mitochondrial Variation across the Archipelago of Tierra del Fuego. Mastozoología Neotropical, 17, 43-52.

31. Fasanella, M. and Lizarralde, M.S. (2012) The Invasive Beaver Castor canadensis in the Tierra del Fuego Archipelago: A Mitochondrial DNA and Spatial Genetic Structure. In: Blanco, J.J.a.F.A.T., Ed., Invasive Species: Threats, Ecological Impact and Control Methods, New York, 101-122.

32. Gabrielli, M., Cardoso, Y.P., Benitez, V., Gozzi, A., Guichón, M., et al. (2014) Genetic Characterization of Callosciurus (Rodentia: Sciuridae) Asiatic Squirrels Introduced in Argentina. Italian Journal of Zoology, 81, 328-343. https://doi.org/10.1080/11250003.2014.940006

33. Bonino, N.A. and Soriguer, R.C. (2008) Genetic Lineages of Feral Populations of the Oryctolagus cuniculus (Leporidae, Lagomorpha) in Argentina. Mammalia, 72, 355-357. https://doi.org/10.1515/MAMM.2008.051 
34. Gabrielli, M., Fasanella, M., Poljak, S. and Lizarralde, M.S. (2008) Variabilidad del ADN Mitocondrial en una población de jabalí (Sus scrofa) del Parque Nacional El Palmar. XXII Jornadas Argentinas de Mastozoología Córdoba.

35. Gabrielli, M., Fasanella, M., Poljak, S., Merino, M. and Lizarralde, M. (2008) Análisis de la variabilidad genética del jabalí (Sus scrofa) en una población del Parque Nacional El Palmar de interés para su manejo como invasora. M. III Congreso Nacional de la Conservación de la Biodiversidad Buenos Aires.

36. Sagua, M., Figueroa, C., Carpinetti, B., Farace, L., Acosta, D., et al. (2014) Análisis de la Variación Genética de las Poblaciones de Jabalí (Sus scrofa) de Argentina mediante el Gen Mitocondrial Citocromo b. XXVII Jornadas Argentinas de Mastozoología Esquel.

37. Poljak, S., Confalonieri, V., Fasanella, M., Gabrielli, M. and Lizarralde, M.S. (2010) Phylogeography of the Armadillo Chaetophractus villosus (Dasypodidae Xenarthra): Post-Glacial Range Expansion from Pampas to Patagonia (Argentina). Molecular Phylogenetics and Evolution, 55, 38-46. https://doi.org/10.1016/j.ympev.2009.12.021

38. Pietrek, A.G. and Fasola, L. (2014) Origin and History of the Beaver Introduction in South America. Mastozoología Neotropical, 21, 355-359.

39. Wu, G.-S., Yao, Y.-G., Qu, K.-X., Ding, Z.-L., Li, H., et al. (2007) Population Phylogenomic Analysis of Mitochondrial DNA in Wild Boars and Domestic Pigs Revealed Multiple Domestication Events in East Asia. Genome Biology, 8, R245. https://doi.org/10.1186/gb-2007-8-11-r245

40. Scandura, M., Iacolina, L., Crestanello, B., Pecchioli, E., Di Benedetto, M., et al. (2008) Ancient vs. Recent Processes as Factors Shaping the Genetic Variation of the European Wild Boar: Are the Effects of the Last Glaciation Still Detectable? Molecular Ecology, 17, 1745-1762. https://doi.org/10.1111/j.1365-294X.2008.03703.x

41. Poljak, S., Escobar, J., Deferrari, G. and Lizarralde, M. (2007) Un nuevo mamífero introducido en la Tierra del Fuego: El "peludo" Chaetophractus villosus (Mammalia, Dasypodidae) en Isla Grande. Revista Chilena de Historia Natural, 80, 285-294. https://doi.org/10.4067/S0716-078X2007000300003

42. Pochon, X., Bott, N.J., Smith, K.F. and Wood, S.A. (2013) Evaluating Detection Limits of Next-Generation Sequencing for the Surveillance and Monitoring of International Marine Pests. PLoS ONE, 8, e73935. https://doi.org/10.1371/journal.pone.0073935

43. Mahon, A.R., Nathan, L.R. and Jerde, C.L. (2014) Meta-Genomic Surveillance of Invasive Species in the Bait Trade. Conservation Genetics Resources, 6, 563-567. https://doi.org/10.1007/s12686-014-0213-9

44. Hampton, J.O., Spencer, P., Alpers, D.L., Twigg, L.E., Woolnough, A.P., et al. (2004) Molecular Techniques, Wildlife Management and the Importance of Genetic Population Structure and Dispersal: A Case Study with Feral Pigs. Journal of Applied Ecology, 41, 735-743. https://doi.org/10.1111/j.0021-8901.2004.00936.x

45. Berry, O., Algar, D., Angus, J., Hamilton, N., Hilmer, S., et al. (2012) Genetic Tagging Reveals a Significant Impact of Poison Baiting on an Invasive Species. The Journal of Wildlife Management, 76, 729-739. https://doi.org/10.1002/jwmg.295

46. Bebber, D.P., Ramotowski, M.A. and Gurr, S.J. (2013) Crop Pests and Pathogens Move Polewards in a Warming World. Nature Climate Change, 3, 985. https://doi.org/10.1038/nclimate1990

47. Adams, A., van Heezik, Y., Dickinson, K. and Robertson, B. (2014) Identifying Eradication Units in an Invasive Mammalian Pest Species. Biological Invasions, 16, 1481-1496.

48. Alphey, L., McKemey, A., Nimmo, D., Neira Oviedo, M., Lacroix, R., et al. (2013) Genetic Control of Aedes Mosquitoes. Pathogens and Global Health, 107, 170-179. https://doi.org/10.1179/2047773213Y.0000000095

49. Klassen, W. and Curtis, C. (2005) History of the Sterile Insect Technique. In: Dyck, V.A., Hendrichs, J. and Robinson, A.S., Eds., Sterile Insect Technique, New York, 3-36. https://doi.org/10.1007/1-4020-4051-2_1 
50. Esvelt, K.M., Smidler, A.L., Catteruccia, F. and Church, G.M. (2014) Concerning RNA-Guided Gene Drives for the Alteration of Wild Populations. eLife, 3, e03401. https://doi.org/10.7554/eLife.03401

51. Webber, B.L., Raghu, S. and Edwards, O.R. (2015) Opinion: Is CRISPR-Based Gene Drive a Biocontrol Silver Bullet or Global Conservation Threat? Proceedings of the National Academy of Sciences, 112, 10565-10567. https://doi.org/10.1073/pnas.1514258112

52. Novillo, A. and Ojeda, R.A. (2008) The Exotic Mammals of Argentina. Biological Invasions, 10, 1333-1344. https://doi.org/10.1007/s10530-007-9208-8

53. Simberloff, D. (2001) Biological Invasions-How Are They Affecting Us, and What Can We Do about Them? Western North American Naturalist, 308-315.

54. Chown, S.L., Hodgins, K.A., Griffin, P.C., Oakeshott, J.G., Byrne, M., et al. (2015) Biological Invasions, Climate Change and Genomics. Evolutionary Applications, 8, 23-46. https://doi.org/10.1111/eva.12234

55. Simberloff, D., Martin, J.-L., Genovesi, P., Maris, V., Wardle, D.A., et al. (2013) Impacts of Biological Invasions: What's What and the Way Forward. Trends in Ecology \& Evolution, 28, 58-66.

https://doi.org/10.1016/j.tree.2012.07.013 